\title{
Role of TRPV-1 in CGRP-mediated trigeminal sensitization
}

\author{
D Chatchaisak¹, B Chetsawang ${ }^{2}$, SM le Grand ${ }^{3}$, P Govitrapong², A Srikiatkhachorn ${ }^{4 *}$ \\ From The European Headache and Migraine Trust International Congress \\ London, UK. 20-23 September 2012
}

\section{Introduction}

Calcitonin gene-related peptide (CGRP) plays an important role in migraine pathogenesis. Transient receptor potential vanilloid-1 (TRPV1) is a cation channel which is expressed in sensory ganglia and can be activated by a number of pain inducing stimuli. The relationship between CGRP and TRPV-1 is still unclear.

\section{Objective}

to investigate the functional role of CGRP on pain sensitization via the mediation of TRPV1 expression in rat trigeminal ganglion (TG).

\section{Materials and methods}

CGRP (600 ng/ $\mathrm{kg}$ ) was intravenously injected to the Wistar rats (250-300 g). Rat trigeminal ganglia and brainstem were removed 45 and 60 minutes after CGRP or saline injection. The levels of CGRP, TRPV-1, phosphorylated PKC (p-PKC) and cyclic AMP responsive element-binding protein (CREB) in TG were determined by western blotting and by immunochemical and immunofluorescence staining. The c-fos level in trigeminal nucleus caudalis (TNC) was also determined.

\section{Results}

Following CGRP injection, there was a significant increase in the amount of TRPV1, CGRP, p-PKC and CREB were observed in rat TG. In addition, an increase in c-fos levels was also determined in TNC of CGRPtreated rats indicating trigeminal nociception.

\section{Conclusion}

These results indicate the role of TRPV-1 in CGRPevoked trigeminal sensitization. This may explain the

${ }^{4}$ Deaprtment of Physiology, Faculty of Medicine, Chulalongkorn University, Bangkok, Thailand

Full list of author information is available at the end of the article process of peripheral sensitization developed during the attack of migraine.

\section{Author details}

${ }^{1}$ Research Center for Neuroscience, Institute of Molecular Biosciences, Mahidol Universit, Salaya, Nakhonpathom 73170, Thailand. ${ }^{2}$ aResearch Center for Neuroscience, Institute of Molecular Biosciences, Mahidol Universit, Salaya, Nakhonpathom 73170, Thailand. ${ }^{3}$ Department of Pathology, Faculty of Medicine, Chulalongkorn University, Thailand. ${ }^{4}$ Deaprtment of Physiology, Faculty of Medicine, Chulalongkorn University, Bangkok, Thailand.

Published: 21 February 2013

\section{Reference}

1. Goadsby PJ, Edvinsson L, Ekman R: Vasoactive peptide release in the extracerebral circulation of humans during migraine headache. Ann Neurol 1990, 28:183-7, Xu X, Wang P, Zou X, Li D, Fang L, Lin Q. Increases in transient receptor potential vanilloid-1 mRNA and protein in primary afferent neurons stimulated by protein kinase $\mathrm{C}$ and their possible role in neurogenic inflammation. J Neurosci Res 2009:87:482-494.

\section{doi:10.1186/1129-2377-14-S1-P72}

Cite this article as: Chatchaisak et al: Role of TRPV-1 in CGRP-mediated trigeminal sensitization. The Journal of Headache and Pain 2013

14(Suppl 1):P72.

\section{SpringerOpen ${ }^{\circ}$}

(c) 2013 Chatchaisak et al; licensee Springer. This is an Open Access article distributed under the terms of the Creative Commons Attribution License (http://creativecommons.org/licenses/by/2.0), which permits unrestricted use, distribution, and reproduction in any medium, provided the original work is properly cited.
Submit your manuscript to a SpringerOpen ${ }^{\circ}$ journal and benefit from:

- Convenient online submission

- Rigorous peer review

- Immediate publication on acceptance

- Open access: articles freely available online

- High visibility within the field

Retaining the copyright to your article

Submit your next manuscript at $>$ springeropen.com 